\title{
ENDOGENOUS CURRENCY OF PRICE SETTING IN A DYNAMIC OPEN ECONOMY MODEL
}

\author{
Michael B. Devereux \\ Charles Engel \\ Working Paper 8559 \\ http://www.nber.org/papers/w8559 \\ NATIONAL BUREAU OF ECONOMIC RESEARCH \\ 1050 Massachusetts Avenue \\ Cambridge, MA 02138
}

October 2001

We thank participants at a workshop at the Federal Reserve Bank of New York for comments. Devereux thanks SSHRC for financial support. Engel thanks NSF for support. The views expressed herein are those of the authors and not necessarily those of the National Bureau of Economic Research.

(C) 2001 by Michael B. Devereux and Charles Engel. All rights reserved. Short sections of text, not to exceed two paragraphs, may be quoted without explicit permission provided that full credit, including $\odot$ notice, is given to the source. 
Endogenous Currency of Price Setting in a Dynamic Open Economy Model

Michael B. Devereux and Charles Engel

NBER Working Paper No. 8559

October 2001

JEL No. F3, F4

\begin{abstract}
Many papers in the recent literature in open economy macroeconomics make different assumptions about the currency in which firms set their export prices when nominal prices must be preset. But to date, all of these studies take the currency of price setting as exogenous. This paper sets up a simple two-country general equilibrium model in which exporting firms can choose the currency in which they set prices for sales to foreign markets. We make two alternative assumptions about the structure of international financial markets: one where there are complete markets for hedging consumption risk internationally, and the other without risk-sharing possibilities. Our results are quite sharp: exporters will generally wish to set prices in the currency of the country that has the most stable monetary policy. When monetary stability is similar among countries, there is an equilibrium where firms from all countries set their price in the currency of the buyer (local currency pricing). But except for a special case where money variances are exactly identical across countries, there is no equilibrium where all firms set export prices in their own currencies (producer currency pricing).
\end{abstract}

Michael B. Devereux

Department of Economics

University of British Columbia

997-1873 East Mall

Vancouver, B.C. V6T 1Z1

Canada
Charles Engel

Department of Economics

University of Wisconsin

1180 Observatory Drive

Madison, WI 53706-1393

and NBER

cengel@ssc.wisc.edu 
The new Keynesian macroeconomics provides a rationale for sticky nominal prices. When there are menu costs to changing prices, imperfectly competitive firms might find it more profitable to leave prices unchanged when there is a shock to costs or demand than to change the price. There is a growing literature in international macroeconomics building on the new Keynesian sticky price framework that provides microeconomic foundations for analysis of open economies. In a much-cited paper, Obstfeld and Rogoff (1995) assumed that firms set prices in their own currency when selling abroad. Subsequently, a long list of papers has investigated the effects of alternative assumptions about the currency in which firms set prices when selling to foreign markets $\square$ But to date, all of these studies have taken the currency of price setting as exogenous. Realistically however, a firm is unlikely to be indifferent between pricing in domestic or foreign currency. When the firm sells abroad, would it prefer the price to be sticky in the producer's currency or the currencies of consumers?

That question has been addressed previously in the literature, but always in a partial equilibrium setting. The partial equilibrium setting is problematic because it takes as exogenous variables that are influenced by the equilibrium price-setting configuration. For example, the behavior of labor costs or aggregate demand might depend on how prices are set.

We address the question of optimal choice of currency for price setting in a framework closely related to that of Obstfeld and Rogoff (1998). Their model is a two-country general equilibrium framework in which there are sticky nominal prices. The Obstfeld-Rogoff (OR) model makes many simplifying assumptions in order to be able to derive analytical solutions that are helpful for developing intuition. Thus it makes fairly specific assumptions about household's preferences; about production functions; about the probability distributions of shocks to the

\footnotetext{
${ }^{1}$ A partial list is Betts and Devereux (1996), Tille (2000), Devereux and Engel (2000), Devereux, Engel and Tille (1999), Bacchetta and Van Wincoop (2000), Corsetti and Pesenti (2001), and Sutherland (2001),
} 
economy; and about price setting behavior (specifically that prices are reset every period.) We will follow their framework, which allows us to derive some very simple conditions under which firms will either set prices in advance in their own currency ("producer-currency pricing" or PCP), or in consumers' currencies ("local-currency pricing" or LCP).

We emphasize the importance of monetary stability in determining the pricing choice in equilibrium. We find that when there are large differences between the variance of money supplies across countries, there is a tendency for all firms to price in the currency of the country with the most stable money supply. As Guillermo Ortiz (1999), the governor of the Banco de México, has commented:

"The pass-through of exchange rates to inflation was much higher in Mexico than in Canada, Australia or New Zealand. And this has to do a lot with history, with credibility of monetary policies, and this is one of the big challenges that we are facing today in Mexico in the conduct of monetary policy. And we have to really build sufficient credibility so that this passthrough from exchange rate movements to inflation ceases to be such an automatic reaction."

In related work, Taylor (2001) argues along similar lines, making the case that passthrough from both exchange rates and general costs may be endogenously determined by a country's inflation performance.

The essential message of our results may be encapsulated as follows. The more stable is a country's monetary process, relative to its neighbors, the more likely it is that foreign exporters will set their prices in that currency, and the more stable will be that country's price level. By the same token, because this country's exporters will also tend to set their export prices in the

2 Bacchetta and van Wincoop (2000a), Devereux and Engel (2000), and Devereux, Engel, and Tille (1999) have extended the Obstfeld-Rogoff model with uncertainty to the local-currency pricing case, and to pricing schemes that mix local-currency pricing and producer-currency pricing. 
home currency, the price level of the country's trading partners, with less stable monetary processes, will be less stable.

At the same time, the results depend in an important way on the structure of international financial markets. When international financial markets allow for full consumption risk-sharing across countries, it is only relative monetary stability that matters. The country with the more stable monetary process will have all world exports priced in its currency, even if neighboring countries also have quite stable monetary processes. But when markets for international risksharing are absent, then absolute monetary volatility becomes important. In this case, as long as all countries have reasonably stable money supplies, we find that the equilibrium configuration of price setting will be that all countries follow LCP, and exchange rate pass-through is zero. But this equilibrium will be eliminated if monetary volatility rises in one country. In that case, all world exports will be priced in the currency of the most stable money supply.

Bacchetta and van Wincoop (2000b) have also recently addressed the question of optimal choice of currency for pricing in a general equilibrium model that differs from ours only slightly in the preference assumptions. They find, as we do, that in the absence of risk-sharing an equilibrium emerges in which all firms in both countries are follow LCP pricing when agents are sufficiently risk averse. ${ }^{\square}$ However, they confine themselves to the case of identical home and foreign money supply processes, so they do not uncover the key result of our paper that the pricing equilibrium is determined by differences in monetary variances across countries. Also, their results are all from numerical simulations, while our analytical results allow us to precisely characterize the conditions for various equilibria to emerge.

In section 1, we lay out the model. In section 2, we derive the equilibrium price-setting behavior under the assumption of complete markets in nominal financial claims. We test the

\footnotetext{
${ }^{3}$ In contrast to us, they find that under complete markets in their set-up there are no pure-strategy equilibria.
} 
sensitivity of our findings to the assumption of financial market completeness by reexamining, in section 3, our conclusions in a setting where no financial claims are traded. Then in section 4 , we discuss broader considerations that are left out of our stylized model.

\section{The model}

Here we outline the features of the models we examine. There are two countries. Infinitely-lived consumers in each country maximize expected lifetime utility, which is a function of consumption, real balances and labor. They take prices and wages as given. There is a continuum of monopolistic firms in each country. Each firm sets prices one period in advance. Firms can set different prices for home and foreign consumers, and can set prices either in their own currency or consumers' currencies. Labor markets are competitive and nominal wages are flexible. We will consider two different asset market structures. In one, there are complete markets in nominal contingent claims. In the other, there is no international trade in assets, and all firms are locally owned. Monetary authorities in each country increase the money supply randomly and nominal exchange rates are floating. Monetary randomness is the only source of uncertainty in the model.

Producers must set prices prior to the realization of monetary shocks. This is an institutional constraint in our model. In section 4 we discuss how menu costs might generate nominal price stickiness. Prices fully adjust to monetary shocks after one period; i.e., there is no persistence to the price-adjustment process.

\footnotetext{
${ }^{4}$ Our results are completely unaffected in both the full risk-sharing and no risk-sharing case if we introduce productivity shocks to the production process. Intuitively, it is because in both cases the equilibrium exchange rate is unaffected by productivity shocks. We omit those shocks from the paper to keep things clean.
} 


\section{Consumers}

The representative consumer in the home country is assumed to maximize

$$
U_{t}=E_{t}\left(\sum_{s=t}^{\infty} \beta^{s-t} u_{s}\right), \quad 0<\beta<1
$$

where

$$
u_{s}=\frac{1}{1-\rho} C_{s}^{1-\rho}+\chi \ln \left(\frac{M_{s}}{P_{s}}\right)-\eta L_{s}, \quad \rho>0
$$

$C$ is a consumption index that is a geometric average of home and foreign consumption:

$$
C=\frac{C_{h}^{n} C_{f}^{1-n}}{n^{n}(1-n)^{1-n}}
$$

We assume that there are $n$ identical individuals in the home country, $0<n<1 . \quad C_{h}$ and $C_{f}$ are indexes over consumption of goods produced at home and in the foreign country, respectively:

$$
C_{h}=\left[n^{-1 / \lambda} \int_{0}^{n} C_{h}(i)^{\lambda-1 / \lambda} d i\right]^{\lambda / \lambda-1} \quad C_{f}=\left[(1-n)^{-1 / \lambda} \int_{h}^{1} C_{f}(i)^{\lambda-1 / \lambda} d i\right]^{\lambda / \lambda-1}
$$

The elasticity of substitution between goods produced within a country is $\lambda$, which we assume to be greater than 1 . There is a unit elasticity of substitution between the home goods and foreign goods indexes. $M / P$ are domestic real balances, and $L$ is the labor supply of the representative home agent.

The price index, $P$, is defined by

$$
P=P_{h}^{n} P_{f}^{1-n}
$$

where

$$
P_{h}=\left[\frac{1}{n} \int_{0}^{n} P_{h}(i)^{1-\lambda} d i\right]^{1 / 1-\lambda} \quad P_{f}=\left[\frac{1}{1-n} \int_{h}^{1} P_{f}(i)^{1-\lambda} d i\right]^{1 / 1-\lambda}
$$


There are $1-n$ identical individuals in the foreign country. Their preferences are similar to home country residents' preferences. The terms in the utility function involving consumption are identical in the home and foreign countries. The functional form for real balances and labor are the same as for the home country residents, but, for foreign residents, they are functions of foreign real balances and foreign labor supply.

The optimal intra-temporal consumption demands are given by:

$$
\begin{array}{cc}
C_{h}(i)=\frac{1}{n}\left[\frac{P_{h}(i)}{P_{h}}\right]^{-\lambda} C_{h} & C_{f}(i)=\frac{1}{1-n}\left[\frac{P_{f}(i)}{P_{f}}\right]^{-\lambda} C_{f} \\
P_{h} C_{h}=n P C & P_{f} C_{f}=(1-n) P C \\
\int_{0}^{n} P_{h}(i) C_{h}(i) d i=P_{h} C_{h} & \int_{h}^{1} P_{f}(i) C_{f}(i) d i=P_{f} C_{f}
\end{array}
$$

We allow for two alternative assets market structures. In one, residents of each country can purchase a full set of state-contingent nominal bonds: there is full international risk-sharing. In the other, the polar opposite, there is no asset trade at all. Residents of one country can only trade in commodities at spot exchange rates, and there are no possibilities for international risksharing in assets markets. While both cases are extremes, this comparison serves to highlight the role of international risk-sharing mechanisms in determining the form of price setting

\section{Full risk-sharing}

When consumers have access to a full set of state contingent bonds, Chari, McGrattan, and Kehoe (2000) show that the following risk-sharing condition (the $C M$ condition) obtains 


$$
\frac{S_{t} \hat{P}_{t}^{*}}{P_{t}}=\Gamma_{0}\left(\frac{C_{t}}{C_{t}^{*}}\right)^{\rho},
$$

where $S_{t}$ is the home currency price of foreign currency, and $\Gamma_{0}$ is a constant, depending on initial conditions. ${ }^{\square} \hat{P}_{t}^{*}$ is the foreign-currency denominated foreign price level. Throughout this paper, the ${ }^{\wedge}$ atop a nominal price indicates that it is denominated in foreign currency, while a $*$ superscript indicates a foreign quantity. Consumption will differ across the two countries only to the extent that there are changes in the real exchange rate.

\section{No risk-sharing}

Without any risk-sharing possibilities, commodity trade must balance across countries, or, equivalently, domestic consumption must equal domestic income. Given our simple specification of preferences, this implies that the nominal value of consumption must be equalized across countries, when evaluated in any one currency:

$$
S_{t} \hat{P}_{t}^{*} C_{t}^{*}=P_{t} C_{t}
$$

In addition to the consumption demand equations listed above, we can derive the money demand equation for the representative home-country resident:

$$
\frac{M_{t}}{P_{t}}=\frac{\chi C_{t}^{\rho}}{1-E_{t}\left(d_{t+1}\right)}
$$

where $E_{t}\left(d_{t+1}\right)$ is the inverse of the gross nominal interest rate, and $d_{t+1}=\beta \frac{C_{t+1}^{-\rho} P_{t}}{C_{t}^{-\rho} P_{t+1}}$ is the pricing kernel for one period ahead dollars. Also, the trade-off between consumption and leisure is given by:

\footnotetext{
${ }^{5}$ When the law of one price holds (as it does when all firms follow PCP pricing), consumption risk is completely shared, even without complete assets markets, as OR (1998) show. But under the LCP specification, the law of one
} 


$$
\frac{W_{t}}{P_{t} C_{t}^{\rho}}=\eta
$$

\section{Government}

Government increases the money supply with direct transfers. The government budget constraint (in per capita terms) is simply

$$
M_{t}=M_{t-1}+T_{t} .
$$

In addition, we assume the money supply follows a random walk:

$$
E_{t}\left(M_{t} / M_{t+1}\right)=1 .
$$

An analogous equation holds for the foreign money supply.

\section{Firms}

Firms are monopolistic competitors. The production function for firm $i$ is given by:

$$
Y_{i t}=L_{i t} \text {, }
$$

where $L_{i t}$ is employment of firm $i$ at time $t$. The objective of the domestic firms is to set prices to maximize the expected utility of the owners. When there is full risk-sharing, it does not matter whether the owners of firms are home or foreign residents. Without risk-sharing, the natural assumption to make is that domestic firms are all owned by domestic residents.

But under either asset market structure, prices must be set before information about random money supplies and productivity shocks is known. The optimization problem can be expressed as one of maximizing the expected present value of profits using the market nominal discount factor for the owners of the firm.

price does not hold. 
While the firm must set prices in advance, it has the option of setting prices in one of two ways:

PCP: Producers set the price in their own currency. The price that foreigners pay for domestic goods, and the price that home residents pay for foreign goods fluctuate when the exchange rate changes.

LCP: Producers set the price in the consumers' currency. Prices consumers face do not respond at all to exchange rate changes.

No state-contingent pricing is allowed.

\section{Equilibrium relationships}

The goods-market equilibrium in the home country is written as:

$$
L_{t}=n \frac{P_{t} C_{t}}{P_{h t}}+(1-n) \frac{P_{t}^{*} C_{t}^{*}}{P_{h t}^{*}}
$$

There is an analogous condition for the foreign country.

It is easy to verify from the money demand equation, (1.3), and the random-walk assumption for money supplies that:

$$
C_{t}^{\rho}=\left(\frac{1-\beta}{\chi}\right) \frac{M_{t}}{P_{t}} .
$$

This implies that the nominal interest rate is constant, in equilibrium. An analogous equation holds for the foreign country.

The solution for the exchange rate depends on the degree of international risk-sharing. Under full risk-sharing, (i.e. condition (1.1)), equation (1.5) give us a solution for the exchange rate:

\footnotetext{
${ }^{6}$ We assume $\Gamma_{0}=1$.
} 


$$
S_{t}=\frac{M_{t}}{M_{t}^{*}}
$$

Without risk-sharing, we may use equation (1.2) and (1.6) to obtain the following solution for the exchange rate:

$$
S_{t}=\left(\frac{M_{t}}{M_{t}^{*}}\right)^{1 / \rho}\left(\frac{\hat{P}_{t}^{*}}{P_{t}}\right)^{1-\rho / \rho} .
$$

While under full risk-sharing, the exchange rate will depend only on the exogenous stochastic realizations of money, while in the economy without risk-sharing the exchange rate will depend on the way in which home and foreign price levels respond to monetary shocks.

Finally, the leisure-consumption tradeoff, (1.4), and equation (1.6) give us

$$
W_{t}=\frac{\eta \chi}{1-\beta} M_{t}
$$

\section{Optimal price setting with full risk-sharing}

Now we look at the decision that firm's make when they set prices in advance. This decision has two parts. The first part concerns which currency the firm should set prices in. Then, given this decision, the firm must choose a price. In each case, the firm maximizes profits evaluated at the discount factor relevant to their owners. We first examine the price setting decision under full risk-sharing.

The question of which currency to choose for price setting can't be examined for one firm in isolation. When prices must be set in advance, the currency of price setting will matter for expected discounted profits of the firm. But the decision over which currency to set prices 
will also depend upon the actions of all other firms, for two reasons. First, the firm (for instance the home firm selling to the foreign country) will compete with all other home firms within the industry, and the currency in which they price in will be relevant. Second, as shown in Devereux and Engel (2000), the currency in which prices are set has macroeconomic implications for aggregate demand, the consumer price index, employment and GDP. Both the volatility and mean of these variables will differ in an economy with PCP relative to an economy with LCP. This may affect the decision faced by any one firm. Thus, in principle the decision over which currency to set prices in is a complex one, depending on the decision made by all other firms. In fact, we will see that our model produces a very simple and intuitive solution.

We adopt the following procedure. First, looking at the home country firm, we ask whether if all home country firms set their export prices in home currency (PCP), is there an incentive for a single home firm to deviate, and set its export price in foreign currency (choose LCP)? If the answer is yes, then we can conclude that PCP is not an equilibrium outcome for home country firms. Then we reverse the question by asking whether if all home country firms were to set their export prices in foreign currency (LCP), there is an incentive for any one home firm to deviate and set its price in domestic currency (choose PCP). If the answer to this is yes, then LCP is not an equilibrium for all home country firms. By looking at the answer to both questions we can see whether PCP or LCP (or possibly both) constitute an equilibrium for home firms. What we find is that the condition to choose LCP when all other firms choose LCP is the same as the condition to choose LCP when all other firms follow PCP. So, if that condition is met, we conclude there is an equilibrium in which all firms follow LCP.

\footnotetext{
${ }^{7}$ In principle, this decision might depend on the pricing decisions of foreign producers also. In fact, as we'll see, it does not, so we can ignore this issue in our description.
} 
Then by employing symmetry, we can look at the decision of foreign firms. Finally, using the results for both home and foreign firms, we can identify an equilibrium configuration of price setting in the world economy.

\section{Home firms follow PCP}

The optimization problem can be expressed as maximizing the expected present value of profits using the market nominal discount factor for the owners of the firm. Since there is no intertemporal aspect to the firms' optimization problems (see, Obstfeld and Rogoff (1998)), this reduces to maximizing one period ahead expected profits in each case. Moreover, because we allow the firm to segment markets by country, we can focus exclusively on the decision over pricing in the foreign market. In the PCP case the firm's expected profit on foreign sales is:

$$
E_{t-1}\left[d_{t-1}\left(P_{h t}^{*}(i) X_{h t}^{*}(i)-W_{t}\left(X_{h t}^{*}(i)\right)\right)\right]
$$

where $X_{h t}^{*}(i)=(1-n) C_{h t}^{*}(i)$ is total sales of firm $i$ to foreign residents. Here, $P_{h t}^{*}(i)$ is the home-currency price for the sale of home firm $i$ to foreign consumers. Recall that the nominal discount factor is $d_{t-1}=\beta \frac{C_{t}^{-\rho} P_{t-1}}{C_{t-1}^{-\rho} P_{t}}=\beta \frac{C_{t}^{*-\rho} S_{t-1} \hat{P}_{t-1}^{*}}{C_{t-1}^{*} S_{t} \hat{P}_{t}^{*}}$, where the second equality makes use of the risk-sharing condition.

From section 1, foreign demand for the home good is

$$
X_{h t}^{*}(i)=(1-n) C_{h t}^{*}(i)=\left[\frac{\hat{P}_{h t}^{*}(i)}{\hat{P}_{h t}^{*}}\right]^{-\lambda} C_{h t}^{*}=n\left[\frac{\hat{P}_{h t}^{*}(i)}{\hat{P}_{h t}^{*}}\right]^{-\lambda} \frac{\hat{P}_{t}^{*} C_{t}^{*}}{\hat{P}_{h t}^{*}}=n\left[\frac{P_{h t}^{*}(i)}{P_{h t}^{*}}\right]^{-\lambda} \frac{S_{t} \hat{P}_{t}^{*} C_{t}^{*}}{P_{h t}^{*}}
$$

Recall that $\mathrm{a}^{\wedge}$ indicates the price is denominated in foreign currency. So $\hat{P}_{h t}^{*}(i)$ is the foreigncurrency price paid by foreign residents for home-produced goods, and $S_{t} \hat{P}_{h t}^{*}(i)=P_{h t}^{*}(i)$.

When all firms follow PCP, the first-order condition for the price of goods sold to foreign consumers is: 


$$
P_{h t}^{*}(i)=P_{h t}^{*}=\frac{\lambda}{\lambda-1} \frac{E_{t-1}\left(W_{t} C_{t}^{* 1-\rho}\right)}{E_{t-1}\left(C_{t}^{* 1-\rho}\right)} .
$$

Note that the derivation of equation (2.1) does not depend on the price-setting decisions of foreign firms, confirming that we can ignore the foreign firms pricing strategy. Using (2.1), we can establish that the expected discounted profit of firm $i$ in the home market earns in period $t$ is given by

$$
\left.E_{t-1}\left[d_{t-1}\left(\left(P_{h t}^{*}(i)-W_{t}\right) X_{h t}^{*}(i)\right)\right)\right]=K_{t-1} E_{t-1}\left(C_{t}^{* 1-\rho}\right)
$$

where $K_{t-1}=\frac{n \beta}{\lambda} \frac{P_{t-1}}{C_{t-1}^{-\rho}}$. Conditional on period $t-1$ variables, expected discounted profit depends only on foreign consumption.

Now consider the potential benefit for firm $i$ if it deviates from all other firms, and sets the price in the foreign currency. Isolating the firm's profits from foreign sales, it maximizes:

$$
\left.E_{t-1}\left\lfloor d_{t-1}\left(\left(S_{t} \hat{P}_{h t}^{* d e v}(i)-W_{t}\right) X_{h t}^{* d e v}(i)\right)\right)\right\rfloor,
$$

where $\hat{P}_{h t}^{* d e v}(i)$ is the foreign-currency price set by the deviating firm, and $X_{h t}^{* d e v}(i)$ is demand for its product given by:

$$
X_{h t}^{* d e v}(i)=(1-n) C_{h t}^{* d e v}(i)=\left[\frac{\hat{P}_{h t}^{* d e v}(i)}{\hat{P}_{h t}^{*}}\right]^{-\lambda} C_{h t}^{*}=n\left[\frac{S_{t} \hat{P}_{h t}^{* d e v}(i)}{P_{h t}^{*}}\right]^{-\lambda} \frac{S_{t} \hat{P}_{t}^{*} C_{t}^{*}}{P_{h t}^{*}}
$$

If firm $i$ sets its price in the foreign currency, a home country nominal depreciation will reduce foreign demand for firm $i$ 's product, relative to demand for all other home goods.

The first-order condition for the optimal choice of $\hat{P}_{h t}^{* d e v}(i)$ is given by:

$$
\hat{P}_{h t}^{* d e v}(i)=\frac{\lambda}{\lambda-1} \frac{E_{t-1}\left(W_{t} S_{t}^{-\lambda} C_{t}^{* 1-\rho}\right)}{E_{t-1}\left(S_{t}^{1-\lambda} C_{t}^{* 1-\rho}\right)}
$$


Note that the deviating price depends directly upon the distribution of the exchange rate, while the optimal price for PCP producers (2.1) does not. Using (2.3) we may establish that the expected discounted profit for the deviating firm is:

$$
K_{t-1} E_{t-1}\left(\left[\frac{P_{h t}^{*}}{S_{t} \hat{P}_{h t}^{* d e v}(i)}\right]^{\lambda-1} C_{t}^{* 1-\rho}\right) .
$$

Substituting in for the optimal prices from expressions (2.1) and (2.3), expression (2.4) can be rewritten as:

$$
K_{t-1}\left(E_{t-1}\left(W_{t} S_{t}^{-\lambda} C_{t}^{* 1-\rho}\right)\right)^{1-\lambda}\left(E_{t-1}\left(S_{t}^{1-\lambda} C_{t}^{* 1-\rho}\right)\right)^{\lambda}\left(E_{t-1}\left(W_{t} C_{t}^{* 1-\rho}\right)\right)^{\lambda-1}\left(E_{t-1}\left(C_{t}^{* 1-\rho}\right)\right)^{1-\lambda}
$$

If wages, consumption and the exchange rate are lognormally distributed, this reduces to:

$$
K_{t-1}\left\{\left(E_{t-1}\left(W_{t} S_{t}^{-\lambda}\right)\right)^{1-\lambda}\left(E_{t-1}\left(S_{t}^{1-\lambda}\right)\right)^{\lambda}\left(E_{t-1}\left(W_{t}\right)\right)^{\lambda-1}\right\} E_{t-1}\left(C_{t}^{* 1-\rho}\right)
$$

If all other firms are follow PCP pricing, then firm $i$ would prefer to deviate and follow an LCP pricing strategy if expected discounted profits by doing so were higher. Comparing expression (2.5) to profits under PCP pricing, given by (2.2), this reduces to the condition

$$
\left(E_{t-1}\left(W_{t} S_{t}^{-\lambda}\right)\right)^{1-\lambda}\left(E_{t-1}\left(S_{t}^{1-\lambda}\right)\right)^{\lambda}\left(E_{t-1}\left(W_{t}\right)\right)^{\lambda-1}>1 .
$$

Under the lognormality assumption, this can be further reduced to the simple expression:

$$
\operatorname{Cov}_{t-1}\left(w_{t}, s_{t}\right)-\frac{1}{2} \operatorname{Var}_{t-1}\left(s_{t}\right)>0,
$$

where lower-case letters are the natural logs of their upper-case counterparts.

We thus obtain a very simple condition determining whether the home firm would wish to deviate from a PCP equilibrium and set prices in foreign currency. The logic behind this condition is easy to obtain. Clearly if there were no variation in the exchange rate, there would be no difference between pricing in domestic and foreign currencies. Thus, the main question is how exchange rate volatility impacts on the expected profit of the deviating firm. Focusing on expression (2.4), we see that exchange rate volatility on its own, holding prices and foreign 
consumption constant, would tend to raise expected discounted profits. For given prices and foreign consumption, expected discounted profits are increasing in exchange rate volatility. But exchange rate volatility also affects the optimal price that the deviating firm sets. Looking at expression (2.3) we see that exchange rate volatility increases the optimal price for the deviating firm. The impact of exchange rate volatility on the firm's optimal deviating price in fact outweighs the direct effect of exchange rate volatility on expected discounted profits, so that we find the net impact of exchange rate volatility on expected discounted profits of the deviating firm is negative. Were this the complete picture, a firm would never wish to deviate from PCP. But exchange rate volatility also has a second indirect effect insofar as exchange rates are correlated with marginal cost. If the exchange rate is positively correlated with marginal cost for the firm, then the optimal price of the deviating firm will be lower (see 2.3), and expected profits higher, given a deviation. Condition (2.7) then just represents the sum of the direct and two indirect effects of exchange rate volatility on expected discounted profits for the deviating firm.

How does condition (2.6) and (2.7) relate to the earlier studies of the currency of price setting decision, based on partial equilibrium analysis (e.g. Giovannini, 1988, Friberg, 1998)? These studies differed in mainly three ways. First, they took aggregate variables (such as foreign demand and the foreign CPI) as given. Second, they were focusing on the decision of a single producer facing a demand curve in isolation, where implicitly the price of all other goods is fixed in foreign currency. Finally, these studies for the most part assumed risk neutrality, so the firm wishes to maximize expected profits alone. In this setting Giovannini (1988) shows that when the demand curve is convex (concave) in own price, the home firm would wish to set price in domestic (foreign) currency.

By contrast, our environment is general equilibrium, where both demand and all other prices are endogenous. In addition however, the firm competes against other domestic firms, so 
the currency in which these other firms set their prices is relevant. In our model, the elasticity of demand between the home good and foreign goods is unity, so under the partial equilibrium analysis of Giovannini (and risk neutrality), this would imply that the home firm would be indifferent to pricing in home or foreign currency. But the relevant comparison for the firm in our environment is between her prices and the prices of domestic competitors. Finally, instead of having risk neutrality, we explicitly condition profits with the stochastic discount factor relevant for the firms' owners. In combination with our full risk-sharing assumption, this in fact eliminates the direct importance of the exchange rate in determining overall demand for home goods, relative to foreign goods. Again, what matters for the firm is the demand for her variety of the home good, relative to the varieties of other home firms.

Following from this discussion, we can make some observations about (2.6) and (2.7). Although we are allowing for the full general equilibrium effects of alternative pricing policies, the conditions governing the optimality of deviating are remarkably simple. In particular, the fact that foreign consumption demand is endogenous is not important to the decision over which prices to set. This is somewhat surprising, since both for PCP pricers in equation (2.1) and LCP deviators in equation (2.3), the covariance of $C_{t}^{* 1-\rho}$ with home nominal wages and the exchange rate matters for the optimal ex ante price. The covariance of $C_{t}^{* 1-\rho}$ with the exchange rate also affects expected discounted profits of the LCP deviator, beyond its influence on prices, as can be seen in equation (2.4). As we noted, the partial equilibrium models of the optimal choice of currency for pricing, such as Giovannini (1988), treat aggregate variables as exogenous and so ignore these covariances. But if $C_{t}^{* 1-\rho}$ were treated as exogenous and uncorrelated with wages and exchange rates in equations (2.1), (2.3), and (2.4), we would still derive equations (2.6) and (2.7) as the condition for choosing LCP when all other firms choose PCP. 
To see this, note that if $C_{t}^{* 1-\rho}$ were independent, we would have $P_{h t}^{* \text { ind }}=\frac{\lambda}{\lambda-1} E_{t-1}(W)$, and $\hat{P}_{h t}^{* d e v-i n d}(i)=\frac{\lambda}{\lambda-1} \frac{E_{t-1}\left(W_{t} S_{t}^{-\lambda}\right)}{E_{t-1}\left(S_{t}^{1-\lambda}\right)}$. Profits of the deviator would then be given by:

$$
\frac{n}{\lambda} E_{t-1}\left[\frac{P_{h t}^{* i n d}}{S_{t} \hat{P}_{h t}^{* d e v-i n d}(i)}\right]^{\lambda-1} E_{t-1}\left(C_{t}^{* 1-\rho}\right)
$$

The condition for deviation to be profitable is then

$$
E_{t-1}\left[\frac{P_{h t}^{* i n d}}{S_{t} \hat{P}_{h t}^{* d e v-i n d}(i)}\right]^{\lambda-1}>1
$$

which is exactly equivalent to conditions (2.6) or (2.7). Thus, the condition to switch to LCP pricing is that the expected value of the optimal PCP price relative to the optimal dollar value of the LCP price (raised to the $\lambda-1$ power) be greater than one.

Condition (2.7) was derived without making reference to the solution for the nominal exchange rate and nominal wages in terms of the money supplies. Now, combining expression (1.7) for the exchange rate, and (1.9) for the nominal wage with condition (2.7), a firm will deviate and follow an LCP pricing strategy when all other firms in the home country follow a PCP strategy if and only if:

$$
\operatorname{Var}_{t-1}\left(m_{t}\right)>\operatorname{Var}_{t-1}\left(m_{t}^{*}\right)
$$

That is, the home firm will wish to deviate from PCP pricing if and only if the volatility of home money exceeds that of foreign money. Moreover, this condition holds irrespective of the covariance of home and foreign money supplies. What matters is only the total monetary volatility, not the covariance across countries.

Now from the results so far, we can state the following propositions: 
Proposition 1: An equilibrium exists in which all home firms are PCP pricers if and only if

$$
\operatorname{Cov}_{t-1}\left(w_{t}, s_{t}\right)-\frac{1}{2} \operatorname{Var}_{t-1}\left(s_{t}\right) \leq 0 \text {. }
$$

Proof: If this condition is met, then no firm will wish to switch to LCP pricing when all other firms are PCP pricing, from condition (2.7).

Corollary: An equilibrium exists in which all home firms are PCP pricers if and only if

$$
\operatorname{Var}_{t-1}\left(m_{t}\right) \leq \operatorname{Var}_{t-1}\left(m_{t}^{*}\right) .
$$

\section{Home firms follow LCP}

Now assume that all home producers set prices in the foreign currency for sales to foreign consumers, and ask whether an individual producer has an incentive to deviate. We can follow the same logic as before. The discounted expected profits from sales to the foreign market are given by:

$$
\left.\left.E_{t-1} \mid d_{t-1}\left(\left(S_{t} \hat{P}_{h t}^{*}(i)-W_{t}\right) X_{h t}^{*}(i)\right)\right)\right\rfloor,
$$

where foreign demand is given by

$$
X_{h t}^{*}(i)=(1-n) C_{h t}^{*}(i)=\left[\frac{\hat{P}_{h t}^{*}(i)}{\hat{P}_{h t}^{*}}\right]^{-\lambda} C_{h t}^{*}=n\left[\frac{\hat{P}_{h t}^{*}(i)}{\hat{P}_{h t}^{*}}\right]^{-\lambda} \frac{\hat{P}_{t}^{*} C_{t}^{*}}{\hat{P}_{h t}^{*}} .
$$

The optimal price for the LCP firm is:

$$
\hat{P}_{h t}^{*}(i)=\hat{P}_{h t}^{*}=\frac{\lambda}{\lambda-1} \frac{E_{t-1}\left(W_{t} S_{t}^{-1} C_{t}^{* 1-\rho}\right)}{E_{t-1}\left(C_{t}^{* 1-\rho}\right)}
$$

The expected discounted profits of these LCP price setters is given by:

$$
K_{t-1} E_{t-1}\left(C_{t}^{* 1-\rho}\right)
$$


Note that this is exactly the expected discounted profit level for firms if they are all PCP price setters. Thus, for a given distribution of foreign consumption, expected profits will be the same if either all home firms follow PCP rules or LCP rules 8

If all other home firms are setting prices in the foreign currency for foreign consumers, firm $i$ might consider setting the price in the home currency. Expected profits for the deviating firm are then given by:

$$
\left.E_{t-1}\left\lfloor d_{t-1}\left(\left(P_{h t}^{* d e v}(i)-W_{t}\right) X_{h t}^{* d e v}(i)\right)\right)\right\rfloor,
$$

where

$$
X_{h t}^{* d e v}(i)=(1-n) C_{h t}^{* d e v}(i)=\left[\frac{P_{h t}^{* d e v}(i)}{S_{t} \hat{P}_{h t}^{*}}\right]^{-\lambda} C_{h t}^{*}=n\left[\frac{P_{h t}^{* d e v}(i)}{S_{t} \hat{P}_{h t}^{*}}\right]^{-\lambda} \frac{\hat{P}_{t}^{*} C_{t}^{*}}{\hat{P}_{h t}^{*}}
$$

The optimal price for the PCP deviator is given by:

$$
P_{h t}^{* d e v}(i)=\frac{\lambda}{\lambda-1} \frac{E_{t-1}\left(W_{t} S_{t}^{\lambda-1} C_{t}^{* 1-\rho}\right)}{E_{t-1}\left(S_{t}^{\lambda-1} C_{t}^{* 1-\rho}\right)}
$$

Using this, the equilibrium expected discounted profits for the PCP deviator are:

$$
K_{t-1} E_{t-1}\left(\left[\frac{S_{t} \hat{P}_{h t}^{*}}{P_{h t}^{*}{ }^{*}(i)}\right]^{\lambda-1} C_{t}^{* 1-\rho}\right)
$$

Substituting the expressions for optimal prices, (2.9) and (2.11), into equation (2.12), the expected discounted profits of the firm that follows the PCP strategy when all others follow LCP are:

$$
K_{t-1}\left(E_{t-1}\left(W_{t} S_{t}^{\lambda-1} C_{t}^{* 1-\rho}\right)\right)^{1-\lambda}\left(E_{t-1}\left(S_{t}^{\lambda-1} C_{t}^{* 1-\rho}\right)\right)^{\lambda}\left(E_{t-1}\left(W_{t} S_{t}^{-1} C_{t}^{* 1-\rho}\right)\right)^{\lambda-1}\left(E_{t-1}\left(C_{t}^{* 1-\rho}\right)\right)^{1-\lambda}
$$

Again, under lognormality, this can be simplified to:

\footnotetext{
${ }^{8}$ In fact however, expected foreign consumption will not be the same. As shown in Devereux and Engel (2000), the presence of LCP (for all firms, both home and foreign) will generate a very different process for output and consumption for both the home and foreign economies than would PCP. But in any case, a comparison of profits from this perspective is not relevant to the question of whether either PCP or LCP constitutes an equilibrium.
} 


$$
K_{t-1}\left\{\left(E_{t-1}\left(W_{t} S_{t}^{\lambda-1}\right)\right)^{1-\lambda}\left(E_{t-1}\left(S_{t}^{\lambda-1}\right)\right)^{\lambda}\left(E_{t-1}\left(W_{t} S_{t}^{-1}\right)\right)^{\lambda-1}\right\} E_{t-1}\left(C_{t}^{* 1-\rho}\right)
$$

Comparing equation (2.13) to the profits for firms that LCP price, it will pay to deviate from LCP pricing if and only if:

$$
\left(E_{t-1}\left(W_{t} S_{t}^{\lambda-1}\right)\right)^{1-\lambda}\left(E_{t-1}\left(S_{t}^{\lambda-1}\right)\right)^{\lambda}\left(E_{t-1}\left(W_{t} S_{t}^{-1}\right)\right)^{\lambda-1}>1
$$

This condition can be expressed as:

$$
\operatorname{Cov}_{t-1}\left(w_{t}, s_{t}\right)-\frac{1}{2} \operatorname{Var}_{t-1}\left(s_{t}\right)<0
$$

If we use the expressions for equilibrium wages and exchange rates, (1.7) and (1.9), then the necessary and sufficient condition for a firm to switch to PCP pricing when all other firms follow an LCP pricing strategy is:

$$
\operatorname{Var}_{t-1}\left(m_{t}\right)<\operatorname{Var}_{t-1}\left(m_{t}^{*}\right)
$$

The following propositions follow:

Proposition 2: An equilibrium exists in which all home firms follow an LCP pricing strategy if and only if

$$
\operatorname{Cov}_{t-1}\left(w_{t}, s_{t}\right)-\frac{1}{2} \operatorname{Var}_{t-1}\left(s_{t}\right) \geq 0 \text {. }
$$

Corollary: An equilibrium exists in which all home firms are follow LCP pricing if and only if

$$
\operatorname{Var}_{t-1}\left(m_{t}\right) \geq \operatorname{Var}_{t-1}\left(m_{t}^{*}\right)
$$

Comparing propositions 1 and 2, we see that there is an equilibrium in which all home firms are LCP pricers if $\left(\operatorname{Cov}_{t-1}\left(w_{t}, s_{t}\right)-\frac{1}{2} \operatorname{Var}_{t-1}\left(s_{t}\right)\right) \geq 0$ or $\operatorname{Var}_{t-1}\left(m_{t}\right) \geq \operatorname{Var}_{t-1}\left(m_{t}^{*}\right)$, and there is

9 Careful examination reveals that the expression on the left-hand side of equation (2.14) equals the inverse of the expression on the left-hand side of equation (2.6) under log normality. 
an equilibrium in which all home firms are PCP pricers if the reverse relationship holds. Moreover, except for the special case of equal monetary variances, the two cannot overlap. When there is an equilibrium where all home firms set prices under PCP, there is generically no equilibrium where they will set prices under PCP, with the reverse statement holding also.

So far, we have looked only at the decision facing home firms. But it turns out that the decision facing foreign firms is identical, given the symmetry of the model. Foreign firms will wish to pre-set prices in foreign currency if the volatility of foreign currency is less than that of domestic currency, and will wish to set prices in home currency if the reverse holds. Then we can go on to state the following proposition:

Proposition 3: There is an equilibrium in which all home and foreign firms set prices in the home currency if and only if:

$$
\operatorname{Var}_{t-1}\left(m_{t}\right) \leq \operatorname{Var}_{t-1}\left(m_{t}^{*}\right) .
$$

There is an equilibrium in which all home and foreign firms set prices in the foreign currency if and only if:

$$
\operatorname{Var}_{t-1}\left(m_{t}\right) \geq \operatorname{Var}_{t-1}\left(m_{t}^{*}\right) .
$$

The pattern is that firms choose to set prices in the currency of the country with the lowest monetary variance.

Note that if one of these inequalities is strict, then there cannot be an equilibrium in which all firms in both countries follow PCP, nor there can there be an equilibrium where all firms in both countries follow LCP. The following proposition follows immediately: 
Propoposition 4: A necessary and sufficient condition for their to be an equilibrium in which all firms in both countries follow a PCP strategy, or in which all firms follow an LCP strategy, is

$$
\operatorname{Var}_{t-1}\left(m_{t}\right)=\operatorname{Var}_{t-1}\left(m_{t}^{*}\right)
$$

Proposition 4 represents a case where there is no unique equilibrium for the choice of price setting currency. Individual firms in the home and foreign countries are indifferent between pricing in either currency.

\section{Optimal price setting without risk-sharing}

To what extent do the results in the previous section depend upon the assumption of full risk-sharing? We investigate this question by moving to the polar opposite assumption of no risk-sharing, so that commodity trade must be balanced in every period. This is represented by condition (1.2).

An important effect of using the trade balance condition instead of complete markets is that the exchange rate is no longer determined by equation (1.7). In the previous analysis, equation (1.7) was important because it obtained irrespective of the pricing decisions of firms. When equation (1.2) holds, then equation (1.8) gives us the equilibrium expression for the exchange rate. It is clear that (except when $\rho=1$ ) the exchange rate will in depend on how home and foreign price levels respond to monetary shocks.

We will show that we can derive propositions that are similar to Proposition 1 and Proposition 2, in the absence of asset trade. However, the corollaries to both propositions do not in general hold in this case. That is, the determinants of the currency of pricing involve more than just the rankings of monetary variances. We follow the same set of steps. 


\section{Home firms follow PCP}

If all firms follow PCP pricing, then expected discounted profit earned in foreign markets, foreign demand, and the discount factor are all defined as before $\frac{10}{\square}$

When all firms follow PCP, the the first-order condition for the price of goods sold to foreign consumers is:

$$
P_{h t}^{*}(i)=P_{h t}^{*}=\frac{\lambda}{\lambda-1} \frac{E_{t-1}\left(W_{t} C_{t}^{1-\rho}\right)}{E_{t-1}\left(C_{t}^{1-\rho}\right)} .
$$

Note that this differs from the optimal price with full risk-sharing, c.f. equation (2.1), since it is domestic and not foreign consumption now that weights marginal cost in the pricing rule. The expected discounted profit that firm $i$ in the home market earns in period $t$ is given by

$$
K_{t-1} E_{t-1}\left(C_{t}^{1-\rho}\right),
$$

where $K_{t-1}=\frac{n \beta}{\lambda} \frac{P_{t-1}}{C_{t-1}^{-\rho}}$.

Now if an individual home firm deviates and sets its price in foreign currency, it will choose price $\hat{P}_{h t}^{* d e v}(i)$ given by:

$$
\hat{P}_{h t}^{* d e v}(i)=\frac{\lambda}{\lambda-1} \frac{E_{t-1}\left(W_{t} S_{t}^{-\lambda} C_{t}^{1-\rho}\right)}{E_{t-1}\left(S_{t}^{1-\lambda} C_{t}^{1-\rho}\right)} .
$$

The expected discounted profit for the deviating firm is:

$$
K_{t-1} E_{t-1}\left(\left[\frac{P_{h t}^{*}}{S_{t} \hat{P}_{h t}^{* d e v}(i)}\right]^{\lambda-1} C_{t}^{1-\rho}\right) .
$$

\footnotetext{
${ }^{10}$ However, in the absence of full risk sharing, home and foreign discount factors are no longer identical.
} 
Following the same steps as in the previous section (with equations (2.5)-(2.7)), we conclude that under the lognormal assumption, if all other firms are PCP pricers, firm $i$ would prefer to deviate and follow an LCP pricing strategy if and only if:

$$
\left(\operatorname{Cov}_{t-1}\left(w_{t}, s_{t}\right)-\frac{1}{2} \operatorname{Var}_{t-1}\left(s_{t}\right)\right)>0 \text {. }
$$

This is the same condition as (2.7) in the previous section.

However, there is not in general a simple relationship equivalent to equation (2.8) that can be derived from condition (3.1). This is because the exchange rate from (1.8) now depends on the pricing strategies followed by the home and foreign firms. We shall analyze some possible outcomes shortly.

\section{Home firms follow LCP}

Following steps analogous to those of section 2, we find that the optimal price charged to foreign consumers of the home good when all home firms follow an LCP pricing strategy is:

$$
\hat{P}_{h t}^{*}(i)=\hat{P}_{h t}^{*}=\frac{\lambda}{\lambda-1} \frac{E_{t-1}\left(W_{t} S_{t}^{-1} C_{t}^{1-\rho}\right)}{E_{t-1}\left(C_{t}^{1-\rho}\right)}
$$

The expected discounted profits of these LCP price setters is given by:

$$
K_{t-1} E_{t-1}\left(C_{t}^{1-\rho}\right)
$$

The optimal price for a home firm that chooses to deviate and price in its own currency when all other home firms price in the foreign currency is given by:

$$
P_{h t}^{* d e v}(i)=\frac{\lambda}{\lambda-1} \frac{E_{t-1}\left(W_{t} S_{t}^{\lambda-1} C_{t}^{1-\rho}\right)}{E_{t-1}\left(S_{t}^{\lambda-1} C_{t}^{1-\rho}\right)} .
$$

The expected discounted profit for the firm that deviates from PCP pricing is:

$$
K_{t-1} E_{t-1}\left(\left[\frac{S_{t} \hat{P}_{h t}^{*}}{P_{h t}^{* \operatorname{dev}}(i)}\right]^{\lambda-1} C_{t}^{1-\rho}\right)
$$


It will pay to deviate from LCP pricing if and only if:

$$
\operatorname{Cov}_{t-1}\left(w_{t}, s_{t}\right)-\frac{1}{2} \operatorname{Var}_{t-1}\left(s_{t}\right)<0 \text {. }
$$

Likewise, given the symmetry of the model, we can show that the foreign firm will find it advantageous to deviate from PCP if the following condition is met

$$
-\operatorname{Cov}_{t-1}\left(w_{t}^{*}, s_{t}\right)-\frac{1}{2} \operatorname{Var}_{t-1}\left(s_{t}\right)>0,
$$

On the other hand, the foreign firm will find it advantageous to deviate from LCP if

$$
-\operatorname{Cov}_{t-1}\left(w_{t}^{*}, s_{t}\right)-\frac{1}{2} \operatorname{Var}_{t-1}\left(s_{t}\right)<0 \text {. }
$$

How do these conditions translate into restrictions on the underlying monetary variances? To investigate this, we make some conjectures about pricing strategies. Then from the implied behavior of exchange rates, we can establish whether these conjectures represent equilibrium strategies.

First, conjecture that all firms in both countries followed PCP pricing. Then it is easy to show that the law of one price holds for all goods, and given identical preferences, purchasing power parity holds: $S_{t} \hat{P}_{t}^{*}=P_{t}$. From equation (1.8), this implies $S_{t}=\frac{M_{t}}{M_{t}^{*}}$. Then using equation (1.9) for the nominal wage, the necessary and sufficient condition for a home firm to follow PCP pricing when all other home firms follow PCP pricing is:

$$
\operatorname{Cov}_{t-1}\left(w_{t}, s_{t}\right)-\frac{1}{2} \operatorname{Var}_{t-1}\left(s_{t}\right)=\operatorname{Var}_{t-1}\left(m_{t}\right)-\operatorname{Var}_{t-1}\left(m_{t}^{*}\right) \leq 0 \text {. }
$$

In the same way, the necessary and sufficient condition for a foreign firm to follow PCP when all other foreign firms follow PCP is:

$$
-\operatorname{Cov}_{t-1}\left(w_{t}^{*}, s_{t}\right)-\frac{1}{2} \operatorname{Var}_{t-1}\left(s_{t}\right)=\operatorname{Var}_{t-1}\left(m_{t}^{*}\right)-\operatorname{Var}_{t-1}\left(m_{t}\right) \leq 0 \text {. }
$$


These two conditions are incompatible, and so there can be no equilibrium in which all firms follow PCP strategies, except in the special case where $\operatorname{Var}_{t-1}\left(m_{t}\right)=\operatorname{Var}_{t-1}\left(m_{t}^{*}\right)$. So we have the following proposition, which is analogous to Proposition 4 for the case of PCP pricing:

Propoposition 5: A necessary and sufficient condition for the existence of an equilibrium in which all firms in both countries follow a PCP strategy is $\operatorname{Var}_{t-1}\left(m_{t}\right)=\operatorname{Var}_{t-1}\left(m_{t}^{*}\right)$.

Now conjecture that all firms in both countries follow LCP strategies. In this case, both $P_{t}$ and $\hat{P}_{t}^{*}$ are determined at time $t-1$, and $\operatorname{Var}_{t-1}\left(P_{t}\right)=\operatorname{Var}_{t-1}\left(\hat{P}_{t}^{*}\right)=0$. Then using equation (1.8) and (1.9), a necessary and sufficient condition for a given home firm to follow LCP pricing if all other home firms follow LCP pricing is:

$$
\operatorname{Cov}_{t-1}\left(w_{t}, s_{t}\right)-\frac{1}{2} \operatorname{Var}_{t-1}\left(s_{t}\right)=(2 \rho-1) \operatorname{Var}_{t-1}\left(m_{t}\right)-\operatorname{Var}_{t-1}\left(m_{t}^{*}\right)-2(\rho-1) \operatorname{Cov}_{t-1}\left(m_{t}, m_{t}^{*}\right) \geq 0 \text {. }
$$

Similarly, if all foreign firms follow LCP pricing, a necessary and sufficient condition for any given foreign firm to follow LCP pricing is:

$$
-\operatorname{Cov}_{t-1}\left(w_{t}^{*}, s_{t}\right)-\frac{1}{2} \operatorname{Var}_{t-1}\left(s_{t}\right)=(2 \rho-1) \operatorname{Var}_{t-1}\left(m_{t}^{*}\right)-\operatorname{Var}_{t-1}\left(m_{t}\right)-2(\rho-1) \operatorname{Cov}_{t-1}\left(m_{t}, m_{t}^{*}\right) \geq 0 \text {. }
$$

If both of these conditions are met, all firms in both countries will follow LCP pricing.

Proposition 6: There is an equilibrium in which all firms in both countries follow LCP pricing if and only if the following two conditions are met:

$$
\begin{aligned}
& \operatorname{Var}_{t-1}\left(m_{t}\right)+\operatorname{Var}_{t-1}\left(m_{t}^{*}\right) \leq 2 \rho \operatorname{Var}_{t-1}\left(m_{t}\right)-2(\rho-1) \operatorname{Cov}_{t-1}\left(m_{t}, m_{t}^{*}\right), \\
& \operatorname{Var}_{t-1}\left(m_{t}\right)+\operatorname{Var}_{t-1}\left(m_{t}^{*}\right) \leq 2 \rho \operatorname{Var}_{t-1}\left(m_{t}^{*}\right)-2(\rho-1) \operatorname{Cov}_{t-1}\left(m_{t}, m_{t}^{*}\right) .
\end{aligned}
$$


Clearly for large enough $\rho$, both conditions can be met. So, in contrast to the case of full risk-sharing, here it is possible for an equilibrium to exist in which all firms price in the consumers' currencies, even when $\operatorname{Var}_{t-1}\left(m_{t}\right) \neq \operatorname{Var}_{t-1}\left(m_{t}^{*}\right)$.

Proposition 6 therefore allows for a case where all export firms would like to keep their prices fixed in the local currency of sale, rather than their own currency. It requires that consumers be relatively risk averse. The intuition behind the proposition can be developed in light of the discussion of the previous section. We saw there that exchange rate variance, holding marginal costs constant, led to a reduction in profits for the LCP firm relative to the PCP alternative, and reduced the incentive to set prices in the buyer's currency. On the other hand, a positive covariance between the exchange rate and marginal costs tends to raise profits for the LCP firm, and increases the incentive to price in the buyer's currency. But when all firms follow LCP pricing rules, and the coefficient of relative risk aversion exceeds unity, the impact of monetary variance on the exchange rate is dampened, relative to the covariance of the exchange rate and marginal costs. This increases the incentive to follow LCP pricing, and, if the conditions of proposition 6 are met, supports the LCP pricing rule for both countries as an equilibrium, even without identical monetary variances.

Note however, that if monetary variances move out of line too much, then the global LCP pricing equilibrium is eliminated. The conditions of proposition 6 will not hold if one country's monetary variance is too high, relative to the other.

We have shown that generically, global PCP pricing is not an equilibrium. Global LCP pricing can be an equilibrium for high risk aversion, and as long as monetary variances are not too far apart. What about asymmetric pricing equilibria? Is there an equilibrium where all world exporting firms price in home (foreign) currency? 
First, conjecture that all home firms follow PCP pricing and all foreign firms follow LCP pricing. If all foreign firms set prices in advance for home consumers in terms of domestic currency, then $P_{t}$ is predetermined. But, with home firms following a PCP pricing strategy, $\hat{P}_{t}^{*}$ varies with the exchange rate. We have, expressing prices in logs, $\hat{p}_{t}^{*}=-n s_{t}+z_{t-1}$, where $z_{t-1}$ represents predetermined components of the price index.

Using this solution for the foreign CPI in the equation for the exchange rate (1.8), we can establish that a home firm will follow PCP pricing when all other home firms follow PCP pricing if and only if the following condition is met (using (1.9) and (3.1)):

$$
\begin{gathered}
\operatorname{Cov}_{t-1}\left(w_{t}, s_{t}\right)-\frac{1}{2} \operatorname{Var}_{t-1}\left(s_{t}\right)= \\
(2(\rho-1)(1-n)+1) \operatorname{Var}_{t-1}\left(m_{t}\right)-\operatorname{Var}_{t-1}\left(m_{t}^{*}\right)-2(\rho-1)(1-n) \operatorname{Cov}_{t-1}\left(m_{t}, m_{t}^{*}\right) \leq 0
\end{gathered}
$$

Likewise, a foreign firm will follow LCP pricing if all other foreign firms follow LCP pricing if and only if:

$$
\begin{gathered}
-\operatorname{Cov}_{t-1}\left(w_{t}^{*}, s_{t}\right)-\frac{1}{2} \operatorname{Var}_{t-1}\left(s_{t}\right)= \\
(2(\rho-1)(1-n)+1) \operatorname{Var}_{t-1}\left(m_{t}^{*}\right)-\operatorname{Var}_{t-1}\left(m_{t}\right)-2(\rho-1)(1-n) \operatorname{Cov}_{t-1}\left(m_{t}, m_{t}^{*}\right) \geq 0
\end{gathered}
$$

We therefore have the following proposition:

Proposition 7: There is an equilibrium in which all home and foreign firms set prices in the home currency if and only if the following two conditions are met:

$$
\begin{aligned}
& \operatorname{Var}_{t-1}\left(m_{t}\right)-\operatorname{Var}_{t-1}\left(m_{t}^{*}\right) \leq-2(\rho-1)(1-n)\left(\operatorname{Var}_{t-1}\left(m_{t}\right)-\operatorname{Cov}_{t-1}\left(m_{t}, m_{t}^{*}\right)\right), \\
& \operatorname{Var}_{t-1}\left(m_{t}\right)-\operatorname{Var}_{t-1}\left(m_{t}^{*}\right) \leq 2(\rho-1)(1-n)\left(\operatorname{Var}_{t-1}\left(m_{t}^{*}\right)-\operatorname{Cov}_{t-1}\left(m_{t}, m_{t}^{*}\right)\right) .
\end{aligned}
$$

A necessary condition for these two conditions to be met is $\operatorname{Var}_{t-1}\left(m_{t}\right) \leq \operatorname{Var}_{t-1}\left(m_{t}^{*}\right)$. 
The symmetry of the home and foreign country allows us to derive the following proposition for the alternative case, where all exports are priced in foreign currency:

Proposition 8: There is an equilibrium in which all home and foreign firms set prices in the foreign currency if and only if the following two conditions are met:

$$
\begin{gathered}
\operatorname{Var}_{t-1}\left(m_{t}^{*}\right)-\operatorname{Var}_{t-1}\left(m_{t}\right) \leq-2(\rho-1) n\left(\operatorname{Var}_{t-1}\left(m_{t}^{*}\right)-\operatorname{Cov}_{t-1}\left(m_{t}, m_{t}^{*}\right)\right), \\
\operatorname{Var}_{t-1}\left(m_{t}^{*}\right)-\operatorname{Var}_{t-1}\left(m_{t}\right) \leq 2(\rho-1) n\left(\operatorname{Var}_{t-1}\left(m_{t}\right)-\operatorname{Cov}_{t-1}\left(m_{t}, m_{t}^{*}\right)\right) .
\end{gathered}
$$

A necessary condition for these two conditions to be met is $\operatorname{Var}_{t-1}\left(m_{t}^{*}\right) \leq \operatorname{Var}_{t-1}\left(m_{t}\right)$.

Propositions 7 and 8 cannot both be met, except in the special case in which the log money supplies are equat. 11 That is, it is generically not possible to have one equilibrium in which all firms price in the home currency and simultaneously another equilibrium in which all firms price in the foreign currency. Note also that for either proposition 7 or proposition 8 to hold, it is necessary that the monetary variances are quite far apart. That is, the condition $\operatorname{Var}_{t-1}\left(m_{t}\right) \leq \operatorname{Var}_{t-1}\left(m_{t}^{*}\right)\left(\operatorname{Var}_{t-1}\left(m_{t}^{*}\right) \leq \operatorname{Var}_{t-1}\left(m_{t}\right)\right)$ is not a sufficient condition for proposition 7 (proposition 8). If risk aversion is greater than unity, and reasonably large, and the monetary variances differ only slightly, then neither of these propositions will apply. In that case, proposition 6 will represent the only pricing equilibrium in the economy without full risksharing 12

11 Another case in which both propositions could be met is $\rho=1$ and equal monetary variances.

12 Nevertheless, it is possible for the conditions of Proposition 6 to be met at the same time that the conditions of either Proposition 7 or Proposition 8 are met. That implies there can be situations of multiple equilibria. If home monetary variance is smaller than foreign monetary variance, then it is possible that there will exist both an equilibrium in which all firms price in the home currency and one in which they all follow LCP pricing. And, if home monetary variance exceeds foreign monetary variance, it is possible that there will exist both an equilibrium in which all firms price in the foreign currency and one in which they all follow LCP pricing. 
The economy without full risk-sharing then offers us some interesting conclusions regarding the equilibrium configuration of international pricing. First, it is generically not possible to have exporters in all countries set prices in their domestic currency. It is possible that exporters will choose to set prices in the currency of the buyer, so long as risk aversion is relatively large, and the monetary variances are not too far apart. But if the monetary variance of one country is too high, then this equilibrium will be eliminated, and it will be replaced by one in which the country's exporters will set their prices in the currency of the other country, as will the exporting firms in the other country. In addition, if risk aversion is relatively low, we tend to move towards the results of the previous section: all world exports will be set in the prices of the country with the lowest monetary variance.

\section{Discussion and conclusions}

The results of the last two sections depend on the type of international financial markets in existence, and also depend on the degree of risk aversion. It is possible to have multiple equilibria in international price setting arrangements; in the full risk-sharing case this is possible if monetary variances are exactly identical; in the no risk-sharing case this is possible if the monetary variances are different, but not too far apart.

Nevertheless, a very strong message comes out of the result of both sections. A country that has highly volatile monetary policy will find that its import prices will be pre-set in foreign currency, and as a result it will experience a high rate of pass-through from exchange rates to imported good prices. A country with a low volatility of monetary policy is more likely to have its import goods prices set in its own currency, with a very low rate of exchange rate passthrough. When all countries have very low monetary policy volatility, and international financial 
markets are incomplete, we are likely to see emerge a low rate of exchange rate pass-through generally.

These results are consistent with the contention of Ortiz (1999) and the discussion of Taylor (2000), suggesting not only that exchange rate pass-through is endogenous, but that it may depend directly on the degree of predictability in monetary policy. Thus, the results would rationalize why exchange rate pass-through would be high in a country that has historically had quite unstable monetary policy, such as Mexico, and low in countries such as New Zealand and Canada, which have historically benefited from very stable monetary policy.

While our results do lend some support to the view that exchange rate pass-through depends on monetary policy, there are a number of features left out of the present analysis. As in the previous literature in the 'new open economy macroeconomics', we have not discussed why firms must set nominal prices one period in advance. The answer from the new Keynesian literature is that small "menu costs" make it more profitable for a firm to set prices ahead of time: the loss in profits from not altering prices optimally when there are small demand shocks are second-order, so even very small menu costs imply it is optimal not to change prices. In the international setting, the firm may necessarily have to incur costs of adjusting prices. If prices are set in the home currency, there may be costs associated with adjusting foreign-currency prices, and vice-versa.

One can justify the analysis of the paper, which does not explicitly consider menu costs, by assuming that the costs of adjusting prices are the same whether prices are set in home or foreign currency. If the costs are very different, menu cost considerations might alter the optimal choice of currency for price setting. But it may be that these costs are all quite small, so that the considerations of the previous sections dominate menu cost considerations. It is unfortunately 
difficult to quantify menu costs and compare them to the gains in expected discounted profits that we have focused on.

Therefore, we view this paper as giving only a partial answer to the question of the optimal currency for price setting. Our analysis has expanded on the previous partial equilibrium modeling and we have found that the partial equilibrium results may well be overturned in general equilibrium. But further theoretical and empirical work is needed to incorporate considerations of transactions costs, distribution and intermediate products. 


\section{References}

Bacchetta, Philippe, and Eric van Wincoop, 2000a, Does exchange rate stability increase trade and welfare?, American Economic Review 90, 1093-1109.

Bacchetta, Philippe, and Eric van Wincoop, 2000b, Trade flows, prices and the exchange rate regime, Study Center Gerzensee, mimeo.

Betts, Caroline and Michael B. Devereux, 1996, The exchange rate in a model of pricing to market, European Economic Review, 40, 1007-1021.

Campa, José M., and Linda S. Goldberg, 2001, Exchange rate pass-through into import prices: a macro or micro phenomenon?, Federal Reserve Bank of New York, mimeo.

Chari, V.V., Patrick J. Kehoe, and Ellen R. McGrattan, 2000, Can sticky price models generate volatile and persistent real exchange rates?, National Bureau of Economic Research, working paper no. 7869 .

Corsetti, Giancarlo and Paolo Pesenti, 2001, Optimal interest rate rules and exchange rate passthrough," Federal Reserve Bank of New York, mimeo.

Devereux, Michael B., and Charles Engel, 2000, Monetary policy in the open economy revisited: Price setting and exchange rate flexibility, National Bureau of Economic Research, working paper no. 7665 .

Devereux, Michael B., Charles Engel, and Cédric Tille, 1999, Exchange rate pass-through and the welfare effects of the euro, National Bureau of Economic Research, working paper no. 7382 .

Friberg, Richard, 1998, In which currency should exporters set their prices?, Journal of International Economics 45, 59-76.

Giovannini, Alberto, 1988, Exchange rates and traded goods prices, Journal of International Economics 24, 45-68.

Obstfeld, Maurice, and Kenneth Rogoff, 1995, Exchange rate dynamics redux, Journal of Political Economy 103, 624-60.

Obstfeld, Maurice, and Kenneth Rogoff, 1998, Risk and exchange rates, National Bureau of Economic Research, working paper no. 6694.

Ortiz, Guillermo M., 1999, Dollarization: fad or future for Latin America?, IMF Economic Forum, transcript.

Sutherland, Alan, 2001, Incomplete pass-through and the welfare effects of exchange rate variability, University of St. Andrews, mimeo. 
Taylor, John B., 2000, Low-inflation, pass-through, and the pricing power of firms, European Economic Review 44, 1389-1408.

Tille, Cédric, 2000, 'Beggar-thy-neighbor' or 'beggar thyself'? The income effects of exchangerate fluctuations, Federal Reserve Bank of New York, Staff Report 112. 